\title{
Modeling the Impact of Total Quality Management (TQM) Practices on Market Orientation in Service Organizations
}

\section{(Case Study: Isfahan Refah Kargaran Bank)}

\author{
Dr. Majid Nili Ahmadabadi \\ Department of Management, Najafabad Branch, Islamic Azad University, Isfahan, Iran \\ Tel:+98-912-130-3478Ｅ-mail:Nili2536@gmail.com
}

Dr. Javad Mehrabi ${ }^{1}$

Department of Public Management, Qazvin Branch, Islamic Azad University, Qazvin, Iran Tel:+98-912-209-7984 E-mail:mehrabijavad@yahoo.com

Batool Samangooei

Graduate Student of Business Administration Payame- Nour University, Tehran, Shahre Ray Unit and Educational Services Expert in University of Isfahan, Iran

Tel:+98-913-413-1977 E-mail:bsamangoei@yahoo.com

Accepted: March 25, 2012 Published: May 27, 2012

Doi:10.5296/ijld.v2i3.1860ＵRL: http://dx.doi.org/10.5296/ijld.v2i3.1860

\begin{abstract}
Purpose: purpose of the present survey is to determine degree of relationship and impact of total quality management (TQM) practices on market orientation in service organizations.

Research methodology: this survey was conducted using descriptive-field method. Its primary data was obtained through field study by two TQM and market orientation questionnaires among seventeen selected branches of Refah Kargaran Bank in Isfahan province. Volume of sample included sixty three (63) persons. Multiple regression method, F-test and T-test, ANOVA and correlation tables were used in the survey.

Findings: continuous improvement with $\beta=0.508$ is the first and most effective factor on increasing of market orientation among seven independent variables (training, management commitment, employees' empowerment, customer focus, information, continuous improvement and employees' involvement). Training with $\beta=0.319$ is in the second place and
\end{abstract}

${ }^{1}$ Corresponding Author 
customer focus with $\beta=0.168$ is in the third place. The regression model of this relationship is as below:

$$
\mathrm{Y}=-0 / 303+0.531 \mathrm{x}_{1}+0 / 367 \mathrm{x}_{2}+0 / 222 \mathrm{x}_{3}
$$

Where $\mathrm{x}_{1}$ is continuous improvement, $\mathrm{x}_{2}$ is training, $\mathrm{x}_{3}$ is customer focus and $\mathrm{Y}$ is service quality.

Conclusion: given to obtained results it could be claimed that it is possible to achieve a desirable level of success in business through more precise planning, focusing on several more important and effective principles and given to prioritization of effective factors on market orientation during a shorter period of time and paying lower costs.

Key words: total quality management (TQM), total quality management (TQM) practices, market orientation

\section{Introduction}

Nowadays organizations perform business in a dynamic and complicated environment. Competition among them has seriously been developed, life-cycle of products has been decreased and life-cycle of organizations is rapidly reached its declining phase. Organizations that think about their competitive advantage and apply it desirably can continue their activity in such turbulent and competitive environment. Quality is a competitive weapon which ensures more durability of organizations. Production and operation managers and especially quality managers create such competitive weapon.

Considering customer satisfaction is another competitive advantage which is observed by organizations. Heavy load of customer satisfaction is generally undertaken by the organization and specifically is undertaken by market orientation. Quality improvement in order to attract customer satisfaction is a new competitive weapon that is effective at the time of organizations' collapse and products' declining. Stating quality and customer satisfaction in mission statement of organizations indicates strategic perspective about the company's future. This issue is so important that some specialists of total quality management (TQM) have defined quality as attracting customers' satisfaction and satisfying their needs.

\section{Research literature}

\section{Total quality management and market orientation}

Today almost all managers and administrators of big companies believe in the important issue of customer-based production. Establishment of opinion poll centers and studying the market by manufacturing and service companies has root in such reality. Production or service manufacturers won't have a long-term life without using modern methods of marketing and customer orientation constitutes one of its major principles. Customers are final judges of all manufactured products or services supplied by small and big companies. Therefore, customers' ideas are the most major factor for failure or success of each manufacturing activity. Importance of recognizing customers' needs and production based on such needs is the first step towards systematic application of market-based production. Market-based production means starting movement from the market and recognizing modern needs and expectations of the customer. According to Kohli and Javorski (1990) market orientation is to establish information obtained from the market in the whole organization 
about current and future needs of customers, development and transmission of such information and talent across the organization and responding to it in all levels of the organization. Thus we can claim that concept of market tendency or market orientation at present is an accepted theory among all managers. Senior managers shape values of the organization and determine its directionalities (Hambrig, 1984).

Emphasis of senior managers on market orientation affects the manner of receiving and responding to information. On the other side, commitment of senior management and information are very important elements in total quality management. So it is possible to show clearly that market orientation is affected by TQM elements. Also, market orientation is a fundamental concept in organizational strategies that is often observed in perspective and mission of organizations or qualitative statements of the organization obviously. In other words, organizations that use TQM philosophy in their strategies and apply it are naturally market-orientated organizations. According to Spark (1993) total quality management increases responding to customers' needs that is market orientation and is finally leaded to establish long-term relationships between the organization and the customer. Indeed behavioral elements of market orientation are similar to existing principles in TQM according to the represented definition by Kohli and Javorski (1990).

Market orientation model of Narver and Slater as a structure and concept is composed of three behavioral elements: customer orientation, competitive orientation and inter-functional coordination. The basic assumption behind this approach is that these behaviors reflect a fundamental organizational culture. We can assert that nowadays implemented managerial systems in organizations pave the way for behaviors and cultures and could affect thinking manner by comprehensiveness of managerial methods and companies' tendency to implement them in order to enhance quality. Therefore, it has been tried in this survey to study driving forces of market-oriented behavior from total quality management viewpoint and introduce the most important and effective factor by analyzing internal and mutual relationships in the organization. To put it differently, we want to study the relationship among total quality management practices and market orientation in service organizations through which finding the most important and effective factor is possible.

Table 1- synthetic table

\begin{tabular}{|l|c|c|c|c|c|c|c|}
\hline Factors & $\begin{array}{l}\text { Juran } \\
\mathbf{1 9 8 8}\end{array}$ & $\begin{array}{l}\text { Saraph et } \\
\text { al, 1989 }\end{array}$ & $\begin{array}{l}\text { Flyn et al, } \\
\mathbf{1 9 9 4}\end{array}$ & $\begin{array}{l}\text { Motwani, } \\
\mathbf{2 0 0 1}\end{array}$ & $\begin{array}{l}\text { Antony et } \\
\text { al, 2002 }\end{array}$ & $\begin{array}{l}\text { Hashemi } \\
\mathbf{2 0 0 8}\end{array}$ & $\begin{array}{l}\text { Proposed } \\
\text { model }\end{array}$ \\
\hline Information & - & - & $\sqrt{ }$ & - & - & - & $\sqrt{ }$ \\
\hline Employees' empowerment & - & $\sqrt{ }$ & - & $\sqrt{ }$ & - & $\sqrt{ }$ & $\sqrt{ }$ \\
\hline Customer focus & $\sqrt{ }$ & - & - & - & $\sqrt{ }$ & $\sqrt{ }$ \\
\hline Employees' involvement & $\sqrt{ }$ & $\sqrt{ }$ & $\sqrt{ }$ & - & $\sqrt{ }$ & - & $\sqrt{ }$ \\
\hline Management commitment & - & $\sqrt{ }$ & $\sqrt{ }$ & $\sqrt{ }$ & $\sqrt{ }$ & $\sqrt{ }$ \\
\hline Continuous improvement & $\sqrt{ }$ & - & $\sqrt{ }$ & $\sqrt{ }$ & $\sqrt{ }$ & $-\sqrt{ }$ \\
\hline Training & $\sqrt{ }$ & $\sqrt{ }$ & - & $\sqrt{ }$ & $\sqrt{ }$ & - & $\sqrt{ }$ \\
\hline
\end{tabular}

The above table shows that the most emphasis is on continuous improvement, management commitment, training, employees' involvement, employees' empowerment, customer focus and finally information respectively according to the clear-sighted. 


\section{Proposed model of the survey}

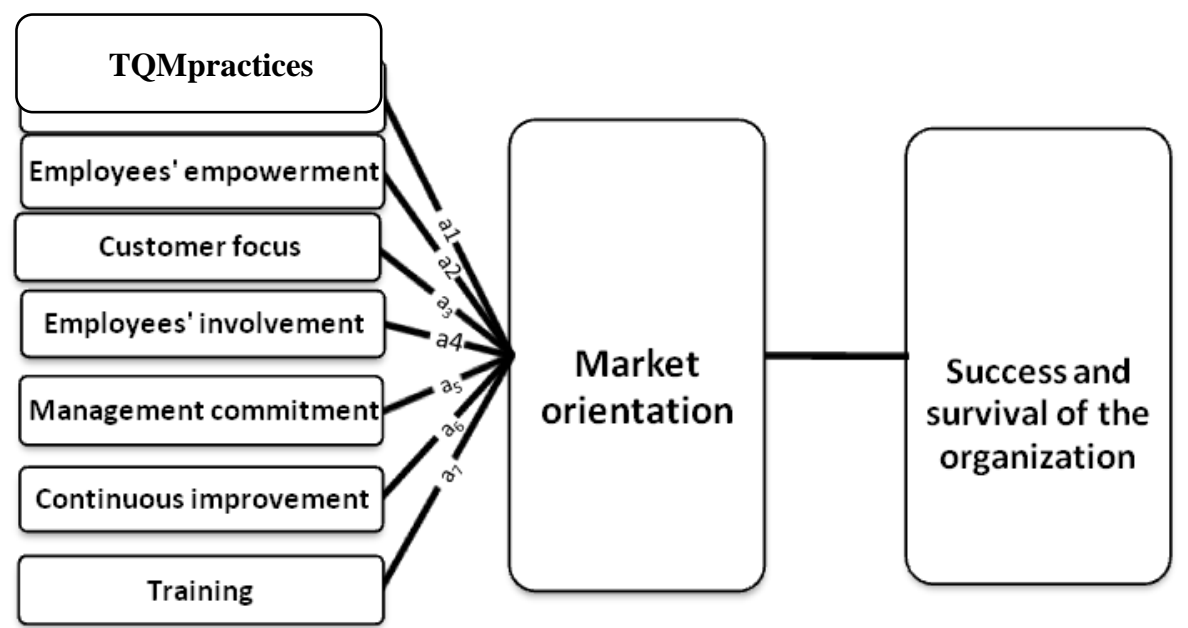

\section{Primary hypotheses}

1) There is a significant relationship among total quality management (TQM) practices and market orientation in service organizations.

2) Total quality management (TQM) practices have different impacts on market orientation.

\section{Secondary hypotheses}

1) There is a significant relationship between continuous improvement and market orientation.

2) There is a significant relationship between customer focus and market orientation.

3) There is a significant relationship between training and market orientation.

4) There is a significant relationship between information and market orientation.

5) There is a significant relationship between employees' empowerment and market orientation.

6) There is a significant relationship between employees' involvement and market orientation.

7) There is a significant relationship between management commitment and market orientation.

\section{Research background}

Nazemi et al (2011) conducted a research entitled "prioritization of key success factors in TQM to decrease performance gap" using fuzzy AHP technique and investigated the issue that which sections are in improvement priority in order to improve current status of total quality in the industry under study. Four components and sixteen sub-components were generally studied in this research. Improvement priority was specified after determining the weight of factors from one side and their gap from the other side by calculating the balanced gap and sub-components of team work, employees' involvement and reward were in first to third priority.

Arumugam et al (2009) conducted a study entitled "self-assessment of total quality management (TQM) practices". This study reveals that power of companies lies in accurate implementation of total quality management (TQM) principles that two important principles of customer focus and processes' management have the highest impact on gaining success. 
But factors such as having relation with suppliers and information have moderating role and are not as important as the above cases.

Boon Ooi (2007) conducted a study entitled "total quality management (TQM) practices and its relationship with production employees". Results of this study illustrate that all practices of total quality management (TQM) don't have a similar impact on production and increasing of employees' job satisfaction. Only organizational culture and team work have a positive relationship with increasing of employees' job satisfaction. This study states that when team work is disseminated as the dominant TQM principle across the whole organization increasing of job satisfaction is appeared significantly.

\section{Research methodology}

First, two questionnaires were compiled for total quality management and service quality using research model and validity of the questionnaire was confirmed through views of academic experts as well as active managers in service industries especially banks. Reliability of the questionnaire was confirmed using cronbach alpha test and was equal to 0.67. Statistical population included two-hundred thirty four (234) employees of branches of Refah Kargaran Bank in Isfahan province. Seventeen branches were selected among thirty five branches of Refah Kargaran Bank by random sampling method and four questionnaires were distributed in each branch. Of course the accessible sample (number of the personnel who were allowed to complete the questionnaire by permission of supervision of branches) was 65 persons that maximum sample volume was used to obtain better results. Descriptive statistics methods such as frequency distribution tables, percentage and mean were applied to study and compare variables. Also referential statistics methods like multiple regression, ANOVA tables, correlation tables and different tests such as F-test and T-test were used to analyze data

in SPSS software.

\section{Data analysis}

\section{Studying variables of TQM practices and market orientation using partial correlation coefficients}

Partial correlation coefficient is correlation between two variables when impacts of other variables are omitted (Nourosis, 2002). Partial coefficient is used when we want to measure power of linear relationship between one dependent variable and one independent variable while impacts of other independent variables are fixed simultaneously. Given to research variables (training, management commitment, employees' empowerment, customer focus, information, continuous improvement and employees' involvement) and the above explanations partial correlation coefficient is used to determine significance relationship among these seven variables. Results are as the following tables: 
Hypothesis $1 \mathrm{H}_{0}$ : there is a significant relationship between continuous improvement and market orientation.

Table 2- testing secondary hypothesis 1: there is a significant relationship between continuous improvement and market orientation.

\begin{tabular}{|c|c|c|c|c|}
\hline \multicolumn{3}{|l|}{ Control variables } & \begin{tabular}{|c|} 
Market orientation \\
1.000
\end{tabular} & $\frac{\text { Continuous improvement }}{.459}$ \\
\hline $\begin{array}{l}\text { Management commitment \& } \\
\text { Employees' involvement \& } \\
\text { Employees' empowerment \& }\end{array}$ & Market orientation & $\begin{array}{l}\text { Correlation } \\
\text { Significance (2-tailed) } \\
\text { Df }\end{array}$ & 1.000 & $\begin{array}{c}.459 \\
.000 \\
55\end{array}$ \\
\hline $\begin{array}{l}\text { Training \& } \\
\text { Customer focus \& } \\
\text { Information }\end{array}$ & $\begin{array}{l}\text { Continuous } \\
\text { improvement }\end{array}$ & $\begin{array}{l}\text { Correlation } \\
\text { Significance (2-tailed) } \\
\text { Df }\end{array}$ & $\begin{array}{l}.459 \\
.000 \\
55\end{array}$ & $\begin{array}{c}1.000 \\
\cdot \\
0\end{array}$ \\
\hline
\end{tabular}

Given to results of table (2) and the obtained partial correlation coefficient between continuous improvement variable and dependent variable of market-orientation (Sig=0.000, partial Correlation $=0.459) \mathrm{H}_{0}$ is rejected. Thus, it is possible to accept the hypothesis regarding existence of positive correlation between continuous improvement and marketorientation.

Hypothesis 2: There is a significant relationship between customer focus and market orientation.

Table 3- testing secondary hypothesis 2: there is a significant relationship between customer focus and market orientation.

\begin{tabular}{|lll|c|c|}
\hline Control variables & & Market orientation & Customer focus \\
\hline Employees' involvement\& & Market orientation & Correlation & 1.000 & .270 \\
Management commitment\& & & Significance (2-tailed) &. & .042 \\
Employees' empowerment\& & & Df & 0 & 55 \\
Information \& Training \& & Customer focus & Correlation & .270 & 1.000 \\
Continuous improvement & & Significance (2-tailed) & .042 &. \\
& & Df & 55 & 0 \\
\hline
\end{tabular}

Given to results of table (3) and the obtained partial correlation coefficient between customer focus variable and dependent variable of market orientation $(\mathrm{Sig}=0.042$, partial Correlation = 0.270) $\mathrm{H}_{0}$ is rejected. Thus, it is possible to accept the hypothesis regarding existence of positive correlation between customer focus and market orientation.

Hypothesis 3: There is a significant relationship between training and market orientation.

Table 4-testing secondary hypothesis 3: there is a significant relationship between training and market orientation. 


\begin{tabular}{|c|c|c|c|c|}
\hline \multicolumn{3}{|l|}{ Control variables } & market orientation & Training \\
\hline $\begin{array}{l}\text { Employees' involvement\& } \\
\text { Management commitment\& } \\
\text { Employees' empowerment\& }\end{array}$ & Market orientation & $\begin{array}{l}\text { Correlation } \\
\text { Significance (2-tailed) } \\
\text { Df }\end{array}$ & $\begin{array}{c}1.000 \\
\cdot \\
0\end{array}$ & $\begin{array}{l}.382 \\
.003 \\
55\end{array}$ \\
\hline $\begin{array}{l}\text { Information \& Training \& } \\
\text { Continuous improvement }\end{array}$ & Training & $\begin{array}{l}\text { Correlation } \\
\text { Significance (2-tailed) } \\
\text { Df }\end{array}$ & $\begin{array}{c}.382 \\
.003 \\
55\end{array}$ & $\begin{array}{c}1.000 \\
\cdot \\
0\end{array}$ \\
\hline
\end{tabular}

Given to results of table (4) and the obtained partial correlation coefficient between training variable and dependent variable of market orientation $(\mathrm{Sig}=0.003$, partial Correlation $=$ 0.382) $\mathrm{H}_{0}$ is rejected. Thus, it is possible to accept the hypothesis regarding existence of positive correlation between training and market orientation.

Hypothesis 4: There is a significant relationship between information and market orientation.

Table 5- testing secondary hypothesis 4: there is a significant relationship between information and market orientation.

\begin{tabular}{|lll|c|c|}
\hline Control variables & & Market orientation & Information \\
\hline Employ involvement \& & Market orientation & Correlation & 1.000 & -.123 \\
Employees' empowerment \& & & Significance (2-tailed) &. & .361 \\
Continuous improvement \& & & Df & 0 & 55 \\
Customer focus \& & Information & Correlation & -.123 & 1.000 \\
Training \& & & Significance (2-tailed) & .361 &. \\
Information & Df & 55 & 0 \\
\hline
\end{tabular}

Given to results of table (5) and the obtained partial correlation coefficient between information variable and dependent variable of market orientation ( $\mathrm{Sig}=0.361>0.05$, partial Correlation $=0.123) \mathrm{H}_{0}$ is not rejected. Thus, it is not possible to accept the hypothesis regarding existence of positive correlation between information and market orientation.

Hypothesis 5: There is a significant relationship between employees' empowerment and market orientation.

Table 6-testing secondary hypothesis 5: there is a significant relationship between employees' empowerment and market orientation.

\begin{tabular}{|lcl|c|c|}
\hline Control variables & & Market orientation & Employees' empowerment \\
\hline Employees' involvement \& & Market orientation & Correlation & 1.000 & .093 \\
Management commitment\& & & Significance (2-tailed) &. & .489 \\
Employees' empowerment \& & & Df & 0 & 55 \\
Training \& & & Correlation & .093 & 1.000 \\
Information\& & empowerment & Significance (2-tailed) & .489 &. \\
Continuous improvement \& & & Df & 55 & 0 \\
Customer focus & & & \\
\hline
\end{tabular}


Given to results of table (6) and the obtained partial correlation coefficient between employees' empowerment variable and dependent variable of market orientation (Sig=0.489> 0.05, partial Correlation $=0.093) \mathrm{H}_{0}$ is not rejected. Thus, it is not possible to accept the hypothesis regarding existence of positive correlation between employees' empowerment and market orientation.

Hypothesis 6: There is a significant relationship between employees' involvement and market orientation.

Table 7- testing secondary hypothesis 6: there is a significant relationship between employees' involvement and market orientation.

\begin{tabular}{|lcl|c|c|}
\hline Control variables & & Market orientation & Employees' involvement \\
\hline Employees' empowerment \& & Market orientation & Correlation & 1.000 & .043 \\
Management commitment\& & & Significance (2-tailed) &. & .753 \\
Information\& & Df & 0 & 55 \\
Continuous improvement \& & Employees' involvement & Correlation & .043 & 1.000 \\
Customer focus \& & & Significance (2-tailed) & .753 &. \\
Training \& & Df & 55 & 0 \\
\hline
\end{tabular}

Given to results of table (7) and the obtained partial correlation coefficient between employees' involvement variable and dependent variable of market orientation ( $\mathrm{Sig}=0.753$ > 0.05 , partial Correlation $=0.043) \mathrm{H}_{0}$ is not rejected. Thus, it is not possible to accept the hypothesis regarding existence of positive correlation between employees' involvement and market orientation.

Hypothesis 7: There is a significant relationship between management commitment and market orientation.

Table 8- testing secondary hypothesis 7: there is a significant relationship between management commitment and market orientation.

\begin{tabular}{|c|c|c|c|c|}
\hline \multicolumn{3}{|l|}{ Control variables } & $\begin{array}{c}\text { Market orientation } \\
1.000\end{array}$ & $\begin{array}{r}\text { Management } \\
\text { commitment } \\
.043\end{array}$ \\
\hline $\begin{array}{l}\text { Employees' empowerment\& } \\
\text { Employees' involvement \& } \\
\text { Information\& }\end{array}$ & Market orientation & $\begin{array}{l}\text { Correlation } \\
\text { Significance (2-tailed) } \\
\text { Df }\end{array}$ & $\begin{array}{c}1.000 \\
\cdot \\
0\end{array}$ & $\begin{array}{c}.043 \\
.751 \\
55\end{array}$ \\
\hline $\begin{array}{l}\text { Continuous improvement \& } \\
\text { Customer focus }\end{array}$ & $\begin{array}{l}\text { Management } \\
\text { commitment }\end{array}$ & $\begin{array}{l}\text { Correlation } \\
\text { Significance (2-tailed) } \\
\text { Df }\end{array}$ & $\begin{array}{r}.043 \\
.751 \\
55\end{array}$ & $\begin{array}{c}1.000 \\
\cdot \\
0\end{array}$ \\
\hline
\end{tabular}

Given to results of table (8) and the obtained partial correlation coefficient between management commitment variable and dependent variable of market orientation ( $\mathrm{Sig}=0.751>$ 0.05, partial Correlation $=0.043) \mathrm{H}_{0}$ is not rejected. Thus, it is not possible to accept the hypothesis regarding existence of positive correlation between management commitment and market orientation. 
Table 9- table of synthetic coefficients

\begin{tabular}{|l|c|c|c|c|c|c|c|}
\hline & \multicolumn{2}{|c|}{$\begin{array}{c}\text { Unstandardized } \\
\text { Coefficients }\end{array}$} & $\begin{array}{c}\text { Standardized } \\
\text { Coefficients }\end{array}$ & \multirow{2}{*}{ T } & \multicolumn{2}{c|}{ Sig } & \multicolumn{2}{c|}{$\begin{array}{c}\text { 95.0\% Confidence } \\
\text { Interval for B }\end{array}$} \\
\cline { 2 - 7 } & B & Std. Error & Beta & & \multicolumn{2}{c}{$\begin{array}{c}\text { Upper } \\
\text { Bound }\end{array}$} & $\begin{array}{c}\text { Lower } \\
\text { Bound }\end{array}$ \\
\hline Constant & $-0 / 387$ & $0 / 345$ & --- & $-1 / 120$ & $0 / 267$ & $0 / 305$ & $-1 / 079$ \\
\hline $\begin{array}{l}\text { Management } \\
\text { commitment (x1) }\end{array}$ & $0 / 035$ & $0 / 110$ & $0 / 039$ & $0 / 319$ & $0 / 751$ & $0 / 255$ & $-0 / 185$ \\
\hline $\begin{array}{l}\text { Employees' } \\
\text { involvement (x2) }\end{array}$ & $0 / 036$ & $0 / 113$ & $0 / 034$ & $0 / 316$ & $0 / 753$ & $0 / 262$ & $-0 / 91$ \\
\hline $\begin{array}{l}\text { Employees' } \\
\text { empowerment (x3) }\end{array}$ & $0 / 083$ & $0 / 119$ & $0 / 067$ & $0 / 969$ & $0 / 489$ & $0 / 322$ & $-0 / 156$ \\
\hline Information (x4) & $-0 / 105$ & $0 / 114$ & $-0 / 101$ & $-0 / 922$ & $0 / 361$ & $0 / 124$ & $-0 / 334$ \\
\hline Training (x5) & $0 / 401$ & $0 / 131$ & $0 / 349$ & $3 / 062$ & $0 / 003$ & $0 / 664$ & $0 / 139$ \\
\hline Customer focus (x6) & $0 / 224$ & $0 / 107$ & $0 / 169$ & $2 / 082$ & $0 / 042$ & $0 / 439$ & $0 / 008$ \\
\hline $\begin{array}{l}\text { Continuous } \\
\text { improvement (x7) }\end{array}$ & $0 / 481$ & $0 / 126$ & $0 / 460$ & $3 / 834$ & $0 / 000$ & $0 / 733$ & $0 / 230$ \\
\hline
\end{tabular}

Given to column B of table (9) it could be perceived that all variables except information have positive coefficients. It means that degree of intention towards market is increased by increasing of their amount. Also it is possible to reject the null hypothesis that coefficients of training $(\mathrm{Sig}=0.003<0.05)$, customer focus $(\mathrm{Sig}=0.042<0.05)$ and continuous improvement $(\mathrm{Sig}=0.000<0.05)$ are equal to zero. It is observed that confidence interval doesn't include zero for these three variables.

But it is not possible to conclude decisively that variables of management commitment ( $\mathrm{Sig}=0.751<0.05)$, employees' involvement $(\mathrm{Sig}=0.753<0.05)$, employees' empowerment $(\mathrm{Sig}=0.489<0.05)$ and information $(\mathrm{Sig}=0.361<0.05)$ don't have a linear relationship with market orientation. It means that any other conclusion about a specific independent variable in multiple regression model depends on the relationship between that variable and other independent variables as well as the dependent variable (Nourosis, 2002). Therefore, table (10) could be used for better interpretation. 


\section{Macrothink}

International Journal of Learning \& Development

ISSN 2164-4063

2012, Vol. 2, No. 3

Table 10- correlation coefficients (power of linear relationship among variables)

\begin{tabular}{|c|c|c|c|c|c|c|c|c|c|}
\hline \multirow{9}{*}{ 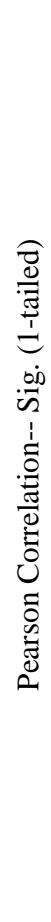 } & & $\begin{array}{c}\text { Market } \\
\text { orientation }\end{array}$ & $\begin{array}{l}\text { Management } \\
\text { commitment }\end{array}$ & $\begin{array}{l}\text { Employees' } \\
\text { involvement }\end{array}$ & $\begin{array}{c}\text { Employees' } \\
\text { empowerment }\end{array}$ & Information & Training & $\begin{array}{l}\text { Customer } \\
\text { focus }\end{array}$ & $\begin{array}{l}\text { Continuous } \\
\text { improvement }\end{array}$ \\
\hline & $\begin{array}{l}\text { Market } \\
\text { orientation }\end{array}$ & $1 / 000$ & $0 / 399$ & $0 / 430$ & $0 / 385$ & $0 / 503$ & $0 / 569$ & $0 / 367$ & $0 / 623$ \\
\hline & $\begin{array}{l}\text { Management } \\
\text { support }\end{array}$ & 0/001 & $1 / 000$ & $0 / 660$ & $0 / 538$ & $0 / 687$ & $0 / 744$ & $0 / 449$ & $0 / 748$ \\
\hline & $\begin{array}{l}\text { Employees' } \\
\text { involvement }\end{array}$ & $0 / 000$ & $0 / 000$ & $1 / 000$ & $0 / 674$ & $0 / 671$ & $0 / 453$ & $0 / 468$ & $0 / 635$ \\
\hline & $\begin{array}{l}\text { Employees' } \\
\text { empowerment }\end{array}$ & 0/001 & $0 / 000$ & $0 / 000$ & $1 / 000$ & $0 / 617$ & $0 / 392$ & $0 / 330$ & $0 / 597$ \\
\hline & Information & $0 / 000$ & $0 / 000$ & $0 / 000$ & $0 / 000$ & $1 / 000$ & $.0 / 669$ & $.0 / 428$ & $.0 / 645$ \\
\hline & Training & $0 / 000$ & $0 / 000$ & $0 / 000$ & 0/001 & $0 / 000$ & $1 / 000$ & $.0 / 452$ & $.0 / 705$ \\
\hline & $\begin{array}{l}\text { Customer } \\
\text { focus }\end{array}$ & $0 / 002$ & $0 / 000$ & $0 / 000$ & $0 / 004$ & $0 / 000$ & $0 / 000$ & $1 / 000$ & $.0 / 577$ \\
\hline & $\begin{array}{l}\text { Continuous } \\
\text { improvement }\end{array}$ & $0 / 000$ & $0 / 000$ & $0 / 000$ & $0 / 000$ & $0 / 000$ & $0 / 000$ & $0 / 000$ & $1 / 000$ \\
\hline
\end{tabular}

The first section of table (10) includes the observed correlation coefficients for each pair of variables and the second section includes observed significant levels. For instance it could observe that correlation coefficient between market orientation and management support and commitment is equal to 0.708 and it is possible to reject the hypothesis that there is no linear relationship between the two variables based on the observed significance level:

$\mathrm{H}_{0}$ : there is no linear relationship between the two variables.

$\mathrm{H}_{1}$ : there is linear relationship between the two variables.

\section{Studying partial regression coefficients}

Coefficients of independent variables are listed in column B in table (10). The primary regression equation is estimated as below using these coefficients:

\section{$Y=-0.387+0.035 X_{1}+0.036 X_{2}+0.083 X_{3}-0.105 X_{4}+0.401 X_{5}+0.224 X_{6}+0.481 X_{7}$}

Market orientation Y, management support and commitment (X1), employees' involvement (X2), employees' empowerment (X3), information (X4), training (X5), customer focus (X6), continuous improvement (X7)

Partial regression coefficients in multiple regression equation show that how much amount of dependent variable is changed by increasing one unit of its amount (of course if amount of other variables is fixed).

\section{Forward selection method}

In this method we begin from the model which has just a fixed amount. At each stage one variable is added to the model which creates the highest change in $\mathrm{R}$ and this change must be so severe to be able to reject the null hypothesis regarding that real amount of change is equal to zero. Insertion of variables in the model is stopped when there is no other variable to create 
a significant increase in $\mathrm{R}$. The regression model has been compiled as below after using forward selection method:

Table 11- summary of the model status

\begin{tabular}{|c|c|c|c|c|c|c|}
\hline Model & & square & $\begin{array}{l}\text { F } \\
\text { change } \\
\text { statistic }\end{array}$ & $\begin{array}{l}\text { De } \\
\text { gree of } \\
\text { freedom } 1\end{array}$ & $\begin{array}{l}\text { Deg } \\
\text { ree of } \\
\text { freedom } 2\end{array}$ & ig \\
\hline $\begin{array}{c}1 \text { constant, continuous } \\
\text { improvement }\end{array}$ & 30.0 & 89.0 & 134 & 1 & 61 & .000 \\
\hline $\begin{array}{l}2 \text { constants, continuous } \\
\text { improvement and training }\end{array}$ & 63.0 & 45.0 & 200. & 1 & 60 & .001 \\
\hline $\begin{array}{l}\text { 3 constants, continuous } \\
\text { improvement, training and customer } \\
\text { focus }\end{array}$ & 74.0 & 63.0 & 655.4 & 1 & 59 & .035 \\
\hline
\end{tabular}

Table 12- regression coefficients

\begin{tabular}{|c|c|c|c|c|c|c|}
\hline & Model & B & $\begin{array}{r}\text { Std } \\
\text {. Error }\end{array}$ & Beta & $\mathbf{T}$ & Sig \\
\hline \multirow{3}{*}{ odel 1} & Constant & 6 & \multirow[b]{2}{*}{2.0} & \multirow{2}{*}{----} & \multirow[t]{2}{*}{732} & \multirow[t]{2}{*}{00} \\
\hline & & $0 / 05$ & & & & \\
\hline & $\begin{array}{l}\text { Continuous } \\
\text { improvement }\end{array}$ & 68.0 & 5.0 & 8300. & $.11 \quad 612$ & 00 \\
\hline \multirow{6}{*}{ odel 2} & Constant & 1 & \multirow[b]{2}{*}{440} & \multirow{2}{*}{----- } & \multirow[t]{2}{*}{.45} & \multirow[b]{2}{*}{00.} \\
\hline & & 11.0 & & & & \\
\hline & Continuous & \multirow[b]{2}{*}{21.0} & \multirow[t]{2}{*}{09} & \multirow{2}{*}{5940.} & \multirow[t]{2}{*}{455} & \multirow[b]{2}{*}{00} \\
\hline & improvement & & & & & \\
\hline & Training & 3 & 10 & \multirow{2}{*}{.3340} & 633 & \multirow[b]{2}{*}{10} \\
\hline & & 84.0 & 60. & & .3 & \\
\hline \multirow{8}{*}{ odel 3} & Constant & 3 & 30 & & .99 & 32 \\
\hline & & 010.- & 4.0 & & $0-0$ & 60. \\
\hline & Continuous & \multirow[b]{2}{*}{310.} & .1 & \multirow{2}{*}{508.0} & \multirow[t]{2}{*}{186} & \multirow[t]{2}{*}{00} \\
\hline & improvement & & 020 & & & \\
\hline & \multirow[t]{2}{*}{ Training } & 0 & 10 & & 564 & .0 \\
\hline & & .367 & 3.0 & & .3 & 010 \\
\hline & Customer focus & 0 & 10 & 1680 & 158 & 03 \\
\hline & & .222 & 30. & & .2 & 5.0 \\
\hline
\end{tabular}

Studying coefficients of column ${ }^{\beta}$

Coefficients of column $\beta$ in table 11 are partial regression coefficients when all independent variables are represented in standardized form. Numbers of column $\beta$ are used to compare relative importance of variables. Thus these numbers illustrate importance of each independent variable. 


\section{Making the final regression model}

Seven variables that have been introduced as independent variables in the model were selected among a large number of variables. Undoubtedly there are other cases which could be useful for making a model. Also some of the selected variables may not be good predictors. The purpose is to constitute a simple model which decreases index errors and improves prediction (Nourosis, 2002). There are various methods to do this and one of them is using forward selection method. According to obtained results of statistical tests and regression models we can claim that 77 percent of market orientation changes are related to three variables of continuous improvement with coefficient 0.531 and training with coefficient 0.367 and customer focus with coefficient 0.222 respectively.

Therefore, its regression model is displayed as below:

Comprehensive model: (market orientation) $\mathrm{Y}=-0 / 303+0.531$ (Continuous improvement) + 0/367(Training) $+0 / 222$ (Customer focus)

\section{Conclusion}

Results reveal that the hypothesis regarding existence of a significant relationship between customer focus and market orientation, training and market orientation and finally continuous improvement and market orientation could be accepted. But hypotheses regarding existence of relationship between market orientation and each practice of management commitment, employees' involvement, employees' empowerment, information could not be accepted given to their significance level in partial correlation analysis. But this issue is not the reason for lack of relationship among these four practices and market orientation. It is notable that some variables contain changes which have been obtained by other variables due to existence of strong and positive relationships among the observed independent variables. For example Pierson correlation coefficient between continuous improvement and management commitment is equal to 0.74 and correlation coefficient between employees' involvement and continuous improvement is equal to 0.635 . That is if continuous improvement is inserted in a model as an independent variable, management support and commitment has no role independently, i.e. most data that information variable contains has been represented by other independent variables too.

The second primary hypothesis (total quality management practices have different impacts on market orientation) is accepted given to various amounts of correlation coefficients as well as various beta amounts in lieu of each variable in the tested regression models. Continuous improvement with $\beta=0.537$ was identified as the most important and effective practice among total quality management practices to enhance the culture of market orientation. Training with $\beta=0.319$ is in the second place after continuous improvement. The third effective factor on market orientation in service organizations is customer focus with $\beta=$ 0.168. A major reason could be that continuous improvement affects general performance of the organization. Commercial strategies, commercial purposes, employees, customers, organizational processes, communications, leadership, resources and etc are fields of continuous improvement. Continuous improvement is one of the elements of total quality 
management for which no end is conceivable. Similarly, training ( $\beta=0.319$ ) is in the second place after continuous improvement that is the most effective practice to enhance market orientation. Customer focus ( $\beta=0.168$ ) is an important factor to reinforce culture of market orientation in the organization. It has the third place after continuous improvement and training among driving practices of market-oriented behavior in the organization.

\section{References}

Nazemi, Sh; Kazemi, M; Okhravi, A, Prioritization of key success factors to decrease performance gap using fuzzy AHP, Case study: an industrial company, two journals of strategic management thought, p 183, No.8, autumn and winter 2011

Nourosis, 2002, translated by Fotouhi, A and Asghari, F, Statistical analysis of data by SPSS, Naghus publications, Tehran

Arumugam, Hiaw Wei Chang, Keng-Boon Ooi, Pei-Lee Teh, (2009) "Self-assessment of TQM practices: a case analysis", The TQM Journal, Vol. 21 Iss: 1, pp.46 - 58

Arumugam et al, "International Journal of Business, Management and Social Sciences"Vol. 1, No. 1, 2010, pp. 113-128

Ooi, Keng Boon; Bakar, Nooh Abu; Veeri, Arumugam; Vellapan, Lorriane; Loke, Alex Kim Yin. (2007). “Does TQM Influence Employees' Job Satisfaction?”, International Journal of Quality \& Reliability Management, Vol. 24, No. 1, PP: 62-77

Saraph, J.V., Benson, P.G. and Schroeder, R.G. (1989), “'An instrument for measuring the critical factors of quality management”, Decision Sciences, Vol. 20 No. 4, pp. 810-29. 